\title{
Detection of CMV Infection in Allogeneic SCT Recipients: The Multiple Assays
}

\author{
Pilar Blanco-Lobo, Omar J. BenMarzouk-Hidalgo and Pilar Pérez-Romero \\ Unit of Infectious Disease, Microbiology and Preventive Medicine, \\ Instituto de Biomedicina de Sevilla (IBiS)/CSIC/Universidad de Sevilla, \\ University Hospital Virgen del Rocio, Sevilla, \\ Spain
}

\section{Introduction}

Cytomegalovirus (CMV) end-organ disease is a serious complication after stem cell transplantation (SCT) (Boeckh M, 2003). Within the first one hundred days after SCT, $50 \%$ of recipients develop CMV infection determined by positive antigenemia and 65 to $86.5 \%$ when viral replication is determined by real-time PCR (RT-PCR) (Ljungman et al., 2006; Solano et al., 2001). Described risk factors for CMV infection concern donor type, graft source, positive $\mathrm{CMV}$ serostatus of donor and recipient, $\mathrm{CD}_{4}{ }^{+}$graft selection, preconditioning regimen, GvHD prophylaxis regimen, incidence of acute and chronic GvHD and prophylaxis and treatment for GvHD (Ljungman et al., 2002; Ozdemir et al., 2007). Pre-emptive therapy is currently based on viral replication determined by either antigenemia or RT-PCR (Drew, 2007). Although antigenemia has been extensively used (Drew, 2007), RT-PCR has been shown to be more sensitive (Hakki et al., 2003; Solano et al., 2001).

The use of techniques based on nucleic acid amplification for the detection of CMV in clinical samples are in expansion and in many hospitals have replaced the use of other assays such as viral cultures or pp65 antigenemia. Several studies have assessed the performance between the different CMV viral load assays available. However, no many studies have compared the differences between the DNA extraction methods used (Fahle \& Fischer, 2000; Caliendo et al., 2007; Kalpoe et al., 2004; Leruez-Ville et al., 2003; Avetisyan et al., 2006; Boeckh et al., 2009; Gerna et al., 2008; Gimeno et al., 2008). Although during the DNA extraction the majority of the methods use internal controls as a measurement of the DNA loss during the extraction procedure, in the downstream amplification not many of the assays use DNA standards that will facilitate the comparison among the different kits and standardization of the results between hospitals. In fact the availability of an optimal and efficient DNA extraction procedure that can use a broad type of samples with minimum modifications in the procedure may be practical and affordable for use in the clinical practice (Fahle \& Fischer, 2000).

One of the differences between results using the methods available is type of clinical specimen used to perform the CMV DNA extraction. Samples collected vary from plasma, 
whole blood or leukocytes, with the optimal sample for monitoring CMV viral being controversial. Since CMV infect cells, the viral load results obtained from leukocytes isolated from peripheral blood or whole blood samples tend to be higher than the results obtained from plasma. However, it has been reported a high correlation between CMV viral load results from plasma samples and whole blood samples (Caliendo et al., 2007; Kalpoe et al., 2004; Leruez-Ville et al., 2003). Moreover, some authors believe that the presence of CMV particles in plasma is related with the level of viral replication (Kalpoe et al., 2004), representing the infectious viral particles able to spread to other host cells. Thus whole blood and plasma samples are equally suitable for testing CMV infection in SCT recipients.

Molecular techniques for CMV quantification such as RT-PCR have been shown to be useful for the rapid diagnosis of CMV infection and for monitoring clinical responses to antiviral therapy. This technique offers some advantages over others PCR methods, including increased precision, accuracy, reproducibility and a shorter turnaround time. To date, the clinical utility of using the RT-PCR test to guide preemptive therapy in transplant recipients has been mainly studied in SCT recipients (Avetisyan et al., 2006; Boeckh M, 2009; Gerna et al., 2008; Gimeno et al., 2008; Harrington et al., 2007; Kalpoe et al., 2004; Lilleri et al., 2004; Limaye et al., 2001; Machida et al., 2000; Ruell et al., 2007; Verkruyse et al., 2006). However, it has not been established a cutoff threshold for initiating antiviral therapy against CMV probably due to the significant differences between the different techniques used to determine the CMV viral load. In the absence of standardization the current clinical guidelines recommend to each individual laboratory to establish their own viral thresholds for CMV management (Kotton et al., 2010; Razonable \& Emery, 2004).

\section{DNA extraction methods}

CMV extraction assays can be performed manually and automated. While manual extraction assays use non-corrosive reagents, are generally inexpensive and are easy to use, they require more labour intensive manipulation increasing the risk for contamination of the samples. In addition, this type of extraction procedures requires highly trained laboratory personnel to ensure reproducible results. Another limitation of the manual assays is the use of ethanol to precipitate the DNA, which may inhibit subsequent RT-PCR assays if not properly removed (Valentine-Thon, 2002). The manual assays are mostly used in research laboratories where the number of samples used at once is not high and the personnel are highly qualified for the procedures.

Automated extraction methods are not widely extended although there are commonly used in clinical services where the number of clinical samples to process every day is high. The main feature of the automated extraction systems is the increase in reproducibility of the extraction among different samples, in addition to a reduction of the risk of contamination and the high number of samples that could be performed at the same time. However, the main handicap of this technology is the elevated cost of the instruments, as well as the highcosts of instruments reagents and maintenance and the necessary laboratory space required (Espy et al., 2006).

While recently reports have shown improvement in the sensibility obtained by the automated extraction instruments in comparison with the manual extraction kits (Gartner 
et al., 2004; Mengelle et al., 2011), and several studies performed on different herpesviruses have shown increased sensibility when automated extraction was performed compared to manual extraction kits (Nicholson et al.; 1997; Griffiths et al.; 1984), our laboratory recently demonstrated that the DNA extraction method from Affigene was more efficient than the automated system from Abbott providing a more accurate estimation of CMV DNA load (Gracia-Ahufinger et al., 2010). Our data proving that the manual DNA extraction method from Affigene resulted in a more efficient DNA extraction in comparison with that of an automated procedure from Abbott were somewhat surprising and are in contrast to previously published studies showing just the opposite (Kalpoe et al., 2004; Limaye et al., 2001). In this context, our data underscore the fact that the DNA extraction efficiency of distinct automated systems may not be comparable and should be thoroughly evaluated. This finding translates into critical therapeutic consequences, as patients would be treated depending on a threshold viral load, which will be different depending on the method used. In this context, these data reinforce the idea that local guidelines for the initiation of pre-emptive therapy based on commercial assays must be established as long as universally accepted standards for quantitative analysis of CMV DNAemia are not available.

\section{Detection of CMV infection}

CMV viral load determination is used to diagnose active CMV infection, to adopt treatment strategies to prevent CMV infection after transplantation and to monitor CMV after therapy. For this reason it is necessary to establish robust and reproducible assays to make possible to detect CMV levels within a wide range from low to very high number of copies (Abbate et al., 2008).

\subsection{CMV detection using antigemia assays}

The pp65 antigenemia developed in the late 1980s was the first non-cell culture based quantitative assay used in clinic to detect CMV infection (Atkinson \& Emery), making obsolete the previous techniques such as shell vial assays (Gleaves et al., 1984; Nicholson et al., 1997), or the detection of early antigen fluorescent foci (DEAFF) test (Griffiths et al., 1984). The pp65 antigenemia assay is based on the detection of the pp65 phosphoprotein of CMV in peripheral blood leukocytes (Van der Bij et al., 1988), and it has been widely used for years to quantify and guiding the administration of therapy and monitoring active CMV infection of STC recipients (Bonon et al., 2005; Tormo et al., 2010). However, the antigenemia assay has many disadvantages such as, it requires quite a lot blood volume as well as intensive labour and need to process samples within $6 \mathrm{~h}$ from the time of collection to achieve optimal sensitivity (Kim et al., 2007; Mhiri et al., 2007), it restricts the numbers of samples that can be analyzed simultaneously and it requires a high number of leukocytes (at least more than 200 leukocytes) for acceptable performance of the assay (Preiser et al., 2001), being unfeasible during periods of severe neutropenia. In addition, due to the fact that antigenemia results can be elevated after following ganciclovir treatment despite of a decrease of DNAemia levels, results using antigenemia for monitoring efficacy of the pre-emptive therapy of CMV infection in SCT recipients may be mislead (Sia et al., 2000). Other molecular techniques have reduced the turnaround time for monitoring CMV infection. 


\subsection{Qualitative PCR assays}

In the past few years new sensitive PCR based techniques have been developed for earlier detection of CMV infection. The new assays developed were initially qualitative and they were able to detect CMV viremia in plasma of SCT recipients, and were compared with antigenemia assay (Boeckh et al., 1997; Boivin et al., 2000; Ksouri et al., 2007; Mori et al., 2000; Preiser et al., 2001). Results from Boivin et al. found a higher sensitivity in antigenemia test, while Boeckh et al. suggested a similar sensibility in both techniques. Most of these studies used in-house PCR assays (Boeckh et al., 1997; Boivin et al., 2000; Preiser et al., 2001), which made difficult to compare results and to conclude the clinical value of the methods (Solano et al., 2001).

The AMPLICOR CMV DNA PCR assay (Roche Diagnostics, Branchburg, N.J.) was the first qualitative technique commercialized. However, despite of being a more sensitive technique, antigenemia was found to be a more suitable technique both for guiding the initiation of preemptive therapy and for monitoring the efficacy of ganciclovir treatment (Solano et al., 2001).

\subsection{Quantitative PCR assays}

The quantitative PCR assays have demonstrated to be more suitable and clinically relevant than qualitative PCR for the detection of CMV DNA (Sia et al., 2000), providing useful information for the management of patients at high risk for developing CMV infection. Quantitative results may facilitate the establishment of a threshold for CMV viral load and the discrimination between patients who had symptomatic CMV infection and those who do not. Thus, allowing to establish the degree of viral replication and to distinguish between low and high level of CMV infection that may lead to disease after SCT (Preiser et al., 2001). Although there are many different commercially available quantitative PCR assays for CMV detection, the COBAS AMPLICOR CMV MONITOR test is one of the more commonly used in the clinical practice. This quantitative PCR developed by Roche included an internal quantification standard. The performance of the assay was found to be more sensitive compared with other qualitative tests (Boivin et al., 2000; Caliendo et al., 2001), with a lower limit of detection of 400 copies/ml of plasma and a dynamic range up to 50,000CMV DNA copies/ml. This assay has been widely used for early detection of $\mathrm{CMV}$ infection in a variety of clinical specimens and clinical studies (Ghisetti et al., 2004; Lehto et al., 2005; Martin-Davila et al., 2005; Piiparinen et al., 2005; Sia et al., 2000; Westall et al., 2004). However, it shows some disadvantages, due to the fact that it requires manual extraction it has a low number of sample processing (24 per run) and a long performance (approximately $8 \mathrm{~h}$ ). In addition, the limit of detection has been established in $2.78 \log 10 \mathrm{cop} / \mathrm{ml}$, value that is high especially for the early detection of CMV replication (Kerschner et al., 2011).

The use of quantitative PCR to detect CMV infection has been highly controversial regarding the specimen used (plasma, whole blood or leukocytes) for the quantification of the CMV viral load (Boeckh et al., 1997; Boivin et al., 2000; Caliendo et al., 2000; Flexman et al., 2001; Kaiser et al., 2002; Machida et al., 2000; Razonable et al., 2002; Tanaka et al., 2000; Weinberg, Schissel, \& Giller, 2002). Some studies have suggested that quantitative PCR measurements for monitoring CMV viral load in whole-blood have a 
higher sensitivity compared to using cells or plasma during CMV disease in immunocompromised patients (Razonable et al., 2002) (von Muller et al., 2007). The authors consider that whole blood includes all the compartments in which the virus can replicate (Deback et al., 2007). In addition, Cortez et al found that quantitative PCR performed in whole blood provided a higher number of positive results $(58.2 \%$ vs. $39.5 \%$ ) compared to plasma (Cortez et al., 2003). However, Leruez-Ville et al. compared the performance of a RT-PCR specifically to amplify high conserved region of CMV UL93 gene in plasma and whole blood, demonstrating that both plasma and whole blood were equally suitable for monitoring active CMV infection (Leruez-Ville et al., 2003).

\subsection{RT-PCR assays}

In the mid 1990s become available the first two commercialized RT-PCR platforms. In the last years, different companies have tried to improve the technique including faster cycling, higher throughput and flexibility, new optical systems and more accessible software (Table 1). For example, it has been developed several versions of the LightCycler instruments such as Roche LightCycler ${ }^{\mathrm{TM}}$ PCR or SmartCycler (Cepheid) for performing sensitive, specific and rapid assays for the detection of CMV, time- and cost-effectiveness and with low contamination risk (Schaade et al., 2000). RT-PCR based on TaqMan probes and related technologies have proven higher dynamic range, precision, accuracy, reproducibility, a shorter turnaround time and a low risk of contamination, offering many advantages over quantitative-competitive PCR assays. With the use of these techniques, the quantification of CMV in clinically relevant samples could be reproducibly achieved in $2 \mathrm{~h}$ allowing to understand CMV replication kinetics in humans (Atkinson \& Emery, 2011). In addition, other advantages have been described about the use of RT-PCR to evaluate the CMV load in HSCT including the ability to test blood during episodes of neutropenia and subsequent disease that had been missed by antigenemia (Kaiser et al., 2002).

On the contrary, RT-PCR also has some disadvantages compared with conventional PCR such as the start-up expense of the assay and the incompatibility of some platforms with certain reagents (Mackay, Arden, \& Nitsche, 2002).

Although most of RT-PCR assays for monitoring CMV infection in SCT recipients have been laboratory developed (Boeckh et al., 2004; Griscelli et al., 2001; Herrmann et al., 2004; Hong et al., 2004; Kalpoe et al., 2004; Leruez-Ville et al., 2003; Lilleri et al., 2004; Limaye et al., 2001; Nitsche et al., 2000; Pumannova et al., 2006; Ruell et al., 2007; Schaade et al., 2000; Tanaka et al., 2000; Tanaka et al., 2002; Yakushiji et al., 2002; Yun et al., 2003), several commercial tests are available and have been used in different clinical diagnostic laboratories. However, there are not many studies based on the application of these commercial assays in SCT recipients (Bravo et al.; Gimeno et al., 2008; Gouarin et al., 2007; Gracia-Ahufinger et al., 2010; Hanson et al., 2007). As it will be described below, these studies evaluated the suitability of the commercial assays for the surveillance of active CMV infection in these patients and compared the performance of the different tests. 


\begin{tabular}{|c|c|c|c|c|}
\hline \multicolumn{5}{|c|}{ LABORATORY DEVELOPED REAL TIME PCR } \\
\hline \multicolumn{3}{|c|}{ ADVANTAGES } & \multicolumn{2}{|l|}{ REF } \\
\hline \multicolumn{3}{|c|}{$\begin{array}{l}\text { Less expensive and with the possibility of being } \\
\text { personally established by developers. }\end{array}$} & \multicolumn{2}{|c|}{$[10,11,17,18,20,56,61,63-71]$} \\
\hline \multicolumn{5}{|c|}{ COMMERCIAL REAL TIME PCR } \\
\hline NAME & MANUFACTURER & $\begin{array}{c}\text { VIRAL } \\
\text { TARGET }\end{array}$ & ADVANTAGES & REF \\
\hline $\begin{array}{c}\text { COBAS } \\
\text { Amplicor CMV } \\
\text { Monitor }\end{array}$ & Roche & UL54 & $\begin{array}{l}\text { Sensitive, low limit of } \\
\text { detection and broad } \\
\text { dynamic range. }\end{array}$ & $\begin{array}{c}{[40-45,} \\
51]\end{array}$ \\
\hline $\begin{array}{c}\text { LightCycler } \\
\text { CMV } \\
\text { Quantitative Kit }\end{array}$ & Roche & UL54 & $\begin{array}{c}\text { Reasonably accurate, } \\
\text { sensitive, specific and } \\
\text { linear. Suitable for the } \\
\text { detection of CMV DNA } \\
\text { early after } \\
\text { transplantation. }\end{array}$ & {$[74,75]$} \\
\hline $\begin{array}{c}\text { Artus CMV } \\
\text { PCR test }\end{array}$ & QIAGEN & UL122 & $\begin{array}{c}\text { Reliable CMV } \\
\text { diagnostic early after } \\
\text { transplantation. } \\
\text { High sensitivity and } \\
\text { performance. }\end{array}$ & 74 \\
\hline CMV R-gene ${ }^{\mathrm{TM}}$ & Argene & UL83 & $\begin{array}{l}\text { Accurate quantification } \\
\text { in SCT patients, good } \\
\text { correlation with other } \\
\text { RT-PCR assays and } \\
\text { pp65 antigenemia. } \\
\text { Validated with several } \\
\text { types of specimen and } \\
\text { DNA purification } \\
\text { systems (automatic and } \\
\text { manual). }\end{array}$ & 73 \\
\hline $\begin{array}{l}\text { Abbott CMV } \\
\text { real-time PCR } \\
\text { Kit }\end{array}$ & Abbott Diagnosis & UL122 & $\begin{array}{l}\text { High sensitivity and } \\
\text { very low limit of } \\
\text { detection }(25 \mathrm{cps} / \mathrm{mL}) \text {. } \\
\text { Good correlation with } \\
\text { antigenemia and } \\
\text { suitable to monitoring } \\
\text { active CMV infection in } \\
\text { SCT patients. }\end{array}$ & {$[15,72]$} \\
\hline $\begin{array}{c}\text { Affigene CMV } \\
\text { Trender }\end{array}$ & Cepheid & Not specified & $\begin{array}{l}\text { Robust, reproducible } \\
\text { and sensitive. Better } \\
\text { analytical performance } \\
\text { than the Abbot test and } \\
\text { accurate estimation of } \\
\text { the viral load. }\end{array}$ & {$[29,28]$} \\
\hline
\end{tabular}

Table 1. Technical advantages of the laboratory developed and commercially available RTPCR methods. 


\subsubsection{Commercial RT-PCR assays}

There are several commercially available RT-PCR assays developed for the detection of CMV infection in clinical samples. Most of these assays use specific targets, such as UL83, UL123 genes or the HXFL4 region (Alain et al.; Caliendo et al., 2007; Gault et al., 2001; Gouarin et al., 2007; Mengelle et al., 2003). The most common targets used for the detection of CMV by RT-PCR are the immediate early (IE) gene (Nitsche et al., 1999), the polymerase (UL54) gene (Schaade et al., 2000) , the glycoprotein B gene (UL55) (Espy et al., 2006) and the pp65 gene (UL83) (Stocher et al., 2003). Among the commercially available standardized methods to detect CMV infection, the LightCycler ${ }^{\circledR}$ CMV Quantitative Kit (Roche), the RealArt CMV LightCycler PCR reagent test (QIAGEN, Germantown, MD), CMV R-geneTM (Argene, France), Affigene CMV Trender (Cepheid, Sweden) and the Abbott CMV real-time PCR Kit (Abbott Diagnosis, USA) have been evaluated in SCT.

The LightCycler ${ }^{\circledR}$ CMV Quantitative assay (Roche) is a standardized RT-PCR test based on analyte-specific reagents (ASR) designed to detect a fragment of $240 \mathrm{pb}$ within the polymerase gene (UL54) (Alain et al.). This test has been compared with the RealArt CMV LightCycler PCR reagent test (QIAGEN) that detects a fragment of $105 \mathrm{pb}$ within the IE gene (Hanson et al., 2007). They made the comparison using OptiQuant CMV DNA panels (AcroMetrix Corp.) that contained four concentrations of CMV strain AD169 and with plasma specimens collected from SCT recipients. Although both tests were suitable to detect CMV DNA early after transplantation, the results using the Qiagen test showed higher sensitivity as well as a better performance at the lower standard concentration (Hanson et al., 2007).

Other remarkable CMV RT-PCR assay is the CMV R-geneTM (Argene, France) that targets the pp65 gene (UL83). This test has been evaluated in SCT recipients from four centers showing an accurate quantification, as well as a good correlation with other laboratorydeveloped RT-PCR assays and pp65 antigenemia, thus the authors suggest that the R-gene test is a good alternative method to diagnose and monitor CMV infection (Gouarin et al., 2007). The Affigene CMV Trender kit was developed by Cepheid and it has been shown to be robust, reproducible and sensitive enough for routine measurement of patient samples (Abbate et al., 2008). The analytical performance of this assay was also evaluated in our laboratory compared with the Abbott CMV RT-PCR Kit, using samples obtained from SCT recipients. The Affigene CMV Trender assay yielded higher viral load than the Abbot test, suggesting a better analytical performance. The comparison was also performed using the OptiQuant CMV DNA quantification panel showing that the Affigene test provides a more accurate estimation of the CMV DNA load (Gracia-Ahufinger et al., 2010). The test manufactured by Abbott, was previously evaluated in plasma samples from SCT recipients (Gimeno et al., 2008).

However the assay was compared with the antigenemia test to monitoring active CMV infection in SCT patients. Results showed a good correlation of the results but higher sensitivity for the RT-PCR assay (Gimeno et al., 2008). More recently the Abbott CMV RTPCR assay was also evaluated in SCT recipients compared with other two commercial tests (Roche and Nanogen) (Bravo et al., 2011). The results found variations in the performance of the tests which limited to establish a common cutoff between different assays. This issue will be discussed below. 


\section{CMV viral load threshold for treatment initiation}

The development of antiviral strategies has resulted in a large decrease in the incidence of CMV disease. Two main therapeutic strategies have been developed for the control of CMV infection and prevention of CMV disease, prophylaxis and pre-emptive therapy. Both strategies have been shown to be equally effective to protect against CMV infection. In the prophylaxis strategy antiviral treatment is administered to all patients after transplantation for a period of time between 100 and 200 days. (Boeckh M, 2003; Hebart \& Einsele, 2004; Meijer et al., 2003; Zaia, 2002). In the pre-emptive strategy treatment is administered only when the CMV viral load reaches an established threshold (Gimeno et al., 2008; Machida et al., 2000). The preemptive administration of treatment consequently requires the use of highly sensitive assay for monitoring CMV viral load.

The International Consensus Guidelines on the Management of CMV after transplantation considered necessary the establishment of a universal cut-off value for initiating therapy (Razonable \& Emery, 2004). Several studies have tried to establish the clinical utility of using the RT-PCR test to guide preemptive therapy in SCT recipients (Avetisyan et al., 2006; Boeckh M, 2009; Gerna et al., 2008; Gimeno et al., 2008; Harrington et al., 2007; Kalpoe et al., 2004; Lilleri et al., 2004; Limaye et al., 2001; Machida et al., 2000; Ruell et al., 2007; Verkruyse et al., 2006). However as stated earlier, there are significant differences between the different techniques used to determine the CMV viral load, thus the standardization of specific cutoff values is limited by the variations in the performance of the test, the assay design, and the diversity in the patient population studied thus results can not be extrapolated. So, it would be necessary an international reference standard between viral loads obtained with different tests. Currently, each laboratory must establish its own cutoff value and monitor clinical outcomes to verify the trigger points used.

Some authors have suggested that pre-emptive therapy should be initiated after two consecutive increased viral load values (Boeckh M, 2009; Gimeno et al., 2008). However, the inter- and intra-assay variability in some cases with variations over $30 \%$ that may represent a risk for using this treatment initiation strategy (Boeckh \& Boivin, 1998; Boeckh \& Nichols, 2004), with variations of the viral load less than $0.5 \mathrm{log}$ may not be significant. Other authors propose considering CMV replication kinetics for the initiation of treatment. In these cases, it needs to be considered that while CMV duplicate within 1-2 days on average, the time for replication is shorter in the presence of immunosuppressant drugs, which may result in faster increase of the viral loads. In addition in these cases may be necessary taking into account the initial viral load since it is predictive of risk for developing CMV disease (Emery \& Griffiths, 2000).

Some studies have established optimal cut-offs for treatment initiation, classifying patients according to the risk for developing CMV disease. A recent publication by Boeckh and Ljungman recommends initiating treatment with viral loads over 100 copies/ml in SCT recipients at high risk for $\mathrm{CMV}$ infection that received the transplant within the last 100 days, and 500 copies/ml for patients at low risk. For long-term SCT recipients initiation of treatment is recommended with viral loads over 1,000 copies/ml (Boeckh M, 2009).

Most of the studies to establish thresholds for the control of CMV infection have been performed using plasma for testing CMV viral load with a wide range of cut-off viral loads varying from 550 copies/ml to 10,000 copies/ml (Avetisyan et al., 2006; Gimeno et al., 2008; 
Hong et al., 2004; Yakushiji et al., 2002). Other studies have established thresholds for the control of CMV infection of 1,000 copies/ml (Boeckh M, 2009; Harrington et al., 2007), and 10,000 (Gerna et al., 2008; Lilleri et al., 2004; Verkruyse et al., 2006) using whole blood. These cut-off values were defined to be protective independently of their CMV sero-status. Few studies have established a protective cut-off for CMV infection in leukocytes; one of these established a cut off of 1,000 CMV genomes copies per 200,000 leukocytes (Avetisyan et al., 2006).

Another important issue after transplantation is the optimal frequency of CMV monitoring which has not been defined for SCT. Most authors recommend a weekly periodicity increased twice a week once CMV replication is detected and during treatment administration, while treatment administration should be interrupted after two consecutive negative determinations (Boeckh M, 2009).

In summary, it has not been established a cutoff threshold for initiating antiviral therapy against CMV maybe due to differences in CMV serological status, immunosuppressive drug regimens and period of treatment. Further studies are necessary in large series of SCT recipients assessing safety of viral load thresholds.

\section{Standardization of CMV viral load quantification}

Since CMV viral loads (in copies per milliliter of body fluid) correlate with the development of CMV disease (Emery \& Griffiths, 2000; Humar et al., 1999), the use of molecular diagnostics based on the measurement of the viral load has contributed to patients' management after transplantation for more than a decade. During preemptive administration of treatment, antiviral therapy is initiated when CMV replication reaches an established threshold in the peripheral blood (Lilleri et al., 2009), prior to develop clinical symptoms. Therefore, the use methods such as RT-PCR can be useful to determine when to initiate the preemptive therapy and its duration (Emery \& Griffiths, 2000; Humar et al., 1999; Humar et al., 2002; Sia \& Patel, 2000) as well as to monitor the response to the administered therapy. However, as previously stated the most important handicap of the available RT-PCR techniques is the high variability of CMV viral load results among different laboratories. Pang et al designed a comparative study among thirty laboratories to evaluate the reproducibility of in-house and commercial assays to detect CMV infection. They prepared a panel of samples with different CMV DNA concentrations that were evaluated in different laboratories, with several commercial available assays. While the intra-laboratory coefficient of variation was considered acceptable (around 17\%), they inter-laboratory variability resulted higher than $140 \%$. These authors considered that differences in viral load lower at $<0.5 \log 10$ are not considered clinically relevant. This difference limits the comparisons inter-laboratories and prevents the establishment of a determinate cut-off broadly applicable for making clinical decisions and monitoring the initiation of pre-emptive therapy (Caliendo et al., 2009). These discrepancies result into clinical therapeutic consequences, as a number of patients may receive treatment in one hospital while not in other hospital using a different assay (Gracia-Ahufinger et al., 2010).

The differences among assays are based on the method for nucleic acid extraction, the specimen type, the target genomic region, primers and probes used for amplification and 
detection (Caliendo et al., 2009; Ikewaki et al., 2005). Although, the variability in the results obtained with commercial assays (kits or ASRs) are proven to be lower than when using inhouse developed methods (Pang et al., 2009).

The most critical factor for standardization is the lack of using an universally accepted standard for CMV quantification will make possible the comparison among results thus establishing a common management of patients in different centers (Atkinson \& Emery, 2011). The reference material used as a calibrator have to be traceable and commutable to achieve accurate clinical results ensuring consistency with clinical samples (Caliendo et al., 2009). While many laboratories produce their own calibrator as an attempt of standardizing some CMV reference material is under development and in fact there are standards commercially available for quantification. For instance, the National Institute of Standards and Technology (NIST) started the development of a reference standard for CMV based on pure CMV DNA from a Towne strain from which after some modification, the final construct will be used to produce viral DNA (Wang et al., 2004). Moreover, the OptiQuant ${ }^{\circledR}$ CMV DNA Quantification Panel from AcroMetrix has been carefully formulated to mimic naturally occurring human specimens containing CMV viral DNA. It consists of cultured CMV that has been diluted in defibrinated, delipidized normal human plasma at different concentrations. The panel can be used with any test procedure designed for measuring CMV DNA in human serum or plasma and it has been widely used as a standard in several studies (Bravo et al.; Forman et al., 2011; Hanson et al., 2007; Raggam et al., 2010) to compare techniques with the same laboratory and inter-laboratory.

In the absence of standardization the current clinical guidelines recommend to each individual laboratory to establish their own viral thresholds for CMV management, (Kotton et al., 2010; Razonable \& Emery, 2004), threshold that cover a wide range of viral loads varying from 200-500 copies/ $\mathrm{mL}$ in some laboratories (Ikewaki et al., 2005; Mori et al., 2002) to $2000-5000$ copies/ $\mathrm{mL}$ in others (Humar et al., 1999).

\section{Conclusions}

In conclusion, the quantitative PCR assays have demonstrated to be more suitable and clinically relevant for the monitoring of the CMV viral load, and the management of patients that develop CMV infection. Although there are several commercially available RT-PCR assays developed for the detection of CMV infection in clinical samples, there are variations in the performance of these tests which limit to establish a common cutoff between different assays. Each laboratory must establish its own cutoff value and monitor clinical outcomes to verify the trigger points used. Using universally accepted standards for CMV quantification will make possible the comparison among results establishing a common management of patients in different centers. However, in the absence of standardization the current clinical guidelines recommend to each individual laboratory to establish their own viral thresholds for CMV management. Further studies are still necessary to establish standardized cut-off values in large series of transplant recipients.

\section{Acknowledgement}

The authors thank other members of the laboratory. P.P-R. was funded by Instituto de Salud Carlos III, Programa Miguel Servet CP05/00226. 


\section{References}

Abbate, I.; Finnstrom, N.; Zaniratti, S.; Solmone, M. C.; Selvaggini, S.; Bennici, E.; Neri, S.; Brega, C.; Paterno, M.; \& Capobianchi, M. R. (2008). Evaluation of an automated extraction system in combination with Affigene CMV Trender for CMV DNA quantitative determination: comparison with nested PCR and pp65 antigen test. J Virol Methods Vol.151, No.1, pp. 61-5, ISSN 0166-0934

Alain, S.; Lachaise, V.; Hantz, S.; \& Denis, F. Comparison between the LightCycler CMV Quant Kit (Roche Diagnostics) with a standardized in-house Taqman assay for cytomegalovirus blood viral load quantification. Pathol Biol (Paris) Vol.58, No.2, pp. 156-61, ISSN 1768-3114

Atkinson, C.; \& Emery, V. C. (2011). Cytomegalovirus quantification: Where to next in optimising patient management? J Clin Virol Vol.51, No.4, pp. 223-8, ISSN 18735967

Avetisyan, G.; Larsson, K.; Aschan, J.; Nilsson, C.; Hassan, M.; \& Ljungman, P. (2006). Impact on the cytomegalovirus (CMV) viral load by CMV-specific T-cell immunity in recipients of allogeneic stem cell transplantation. Bone Marrow Transplant Vol.38, No.10, pp. 687-92, ISSN 0268-3369

Boeckh, M.; \& Boivin, G. (1998). Quantitation of cytomegalovirus: methodologic aspects and clinical applications. Clin Microbiol Rev Vol.11, No.3, pp. 533-54, ISSN 0893-8512

Boeckh, M.; Gallez-Hawkins, G. M.; Myerson, D.; Zaia, J. A.; \& Bowden, R. A. (1997). Plasma polymerase chain reaction for cytomegalovirus DNA after allogeneic marrow transplantation: comparison with polymerase chain reaction using peripheral blood leukocytes, pp65 antigenemia, and viral culture. Transplantation Vol.64, No.1, pp. 108-13, ISSN 0041-1337

Boeckh, M.; Huang, M.; Ferrenberg, J.; Stevens-Ayers, T.; Stensl\&, L.; Nichols, W. G.; \& Corey, L. (2004). Optimization of quantitative detection of cytomegalovirus DNA in plasma by real-time PCR. J Clin Microbiol Vol.42, No.3, pp. 1142-8, ISSN 0095-1137

Boeckh M. (2009). How we treat cytomegalovirus in hematopoietic cell transplant recipients. Blood Vo.113, No.23, pp. 5711-9, ISSN 1528-0020

Boeckh, M.; \& Nichols, W. G. (2004). The impact of cytomegalovirus serostatus of donor \& recipient before hematopoietic stem cell transplantation in the era of antiviral prophylaxis and preemptive therapy. Blood Vol.103, No.6, pp. 2003-8, ISSN 00064971

Boeckh, M.; Papanicolaou, G.; Rubin, R.; Wingard, J.R.; Zaia, J. (2003). CMV in hematopoietic stem cell transplant recipients: Current status, known challenges, and future strategies. Biol. Blood Marrow Transplant Vol.5, pp. 543-558, ISSN 10838791

Boivin, G.; Belanger, R.; Delage, R.; Beliveau, C.; Demers, C.; Goyette, N.; \& Roy, J. (2000). Quantitative analysis of cytomegalovirus (CMV) viremia using the pp65 antigenemia assay and the COBAS AMPLICOR CMV MONITOR PCR test after blood \& marrow allogeneic transplantation. J Clin Microbiol Vol.38, No.12, pp. 435660, ISSN 0095-1137

Bonon, S. H.; Menoni, S. M.; Rossi, C. L.; De Souza, C. A.; Vigorito, A. C.; Costa, D. B.; \& Costa, S. C. (2005). Surveillance of cytomegalovirus infection in haematopoietic stem cell transplantation patients. J Infect Vol.50, No.2, pp. 130-7, ISSN 0163-4453

Bravo, D.; Clari, M. A.; Costa, E.; Munoz-Cobo, B.; Solano, C.; Jose Remigia, M.; \& Navarro, D. (2011). Comparative Evaluation of Three Automated Systems for DNA Extraction in Conjunction with Three Commercially Available Real-Time PCR 
Assays for Quantitation of Plasma Cytomegalovirus DNAemia in Allogeneic Stem Cell Transplant Recipients. J Clin Microbiol Vol.49, No.8, pp. 2899-904, ISSN 1098$660 \mathrm{X}$

Caliendo, A. M.; Ingersoll, J.; Fox-Canale, A. M.; Pargman, S.; Bythwood, T.; Hayden, M. K.; Bremer, J. W.; \& Lurain, N. S. (2007). Evaluation of real-time PCR laboratorydeveloped tests using analyte-specific reagents for cytomegalovirus quantification. J Clin Microbiol Vol.45, No.6, pp. 1723-7, ISSN 0095-1137

Caliendo, A. M.; Schuurman, R.; Yen-Lieberman, B.; Spector, S. A.; \&ersen, J.; Manjiry, R.; Crumpacker, C.; Lurain, N. S.; \& Erice, A. (2001). Comparison of quantitative \& qualitative PCR assays for cytomegalovirus DNA in plasma. J Clin Microbiol Vol.39, No.4, pp. 1334-8, ISSN 0095-1137

Caliendo, A. M.; Shahbazian, M. D.; Schaper, C.; Ingersoll, J.; Abdul-Ali, D.; Boonyaratanakornkit, J.; Pang, X. L.; Fox, J.; Preiksaitis, J.; \& Schonbrunner, E. R. (2009). A commutable cytomegalovirus calibrator is required to improve the agreement of viral load values between laboratories. Clin Chem Vol.55, No.9, pp. 1701-10, ISSN 1530-8561

Caliendo, A. M.; St George, K.; Kao, S. Y.; Allega, J.; Tan, B. H.; LaFontaine, R.; Bui, L.; \& Rinaldo, C. R. (2000). Comparison of quantitative cytomegalovirus (CMV) PCR in plasma \& CMV antigenemia assay: clinical utility of the prototype AMPLICOR CMV MONITOR test in transplant recipients. J Clin Microbiol Vol.38, No.6, pp. 2122-7, ISSN 0095-1137

Cortez, K. J.; Fischer, S. H.; Fahle, G. A.; Calhoun, L. B.; Childs, R. W.; Barrett, A. J.; \& Bennett, J. E. (2003). Clinical trial of quantitative real-time polymerase chain reaction for detection of cytomegalovirus in peripheral blood of allogeneic hematopoietic stem-cell transplant recipients. J Infect Dis Vol.188, No.7, pp. 967-72, ISSN 0022-1899

Deback, C.; Fillet, A. M.; Dhedin, N.; Barrou, B.; Varnous, S.; Najioullah, F.; Bricaire, F.; \& Agut, H. (2007). Monitoring of human cytomegalovirus infection in immunosuppressed patients using real-time PCR on whole blood. J Clin Virol Vol.40, No.3, pp. 173-9, ISSN 1386-6532

Drew, W. L. (2007). Laboratory diagnosis of cytomegalovirus infection and disease in immunocompromised patients. Curr Opin Infect Dis Vol.20, No.4, pp. 408-11, ISSN 0951-7375

Emery, V. C.; \& Griffiths, P. D. (2000). Prediction of cytomegalovirus load and resistance patterns after antiviral chemotherapy. Proc Natl Acad Sci U S A Vol.97, No.14, pp. 8039-44, ISSN 0027-8424

Espy, M. J.; Uhl, J. R.; Sloan, L. M.; Buckwalter, S. P.; Jones, M. F.; Vetter, E. A.; Yao, J. D.; Wengenack, N. L.; Rosenblatt, J. E.; Cockerill, F. R. 3rd; \& Smith, T. F. (2006). Realtime PCR in clinical microbiology: applications for routine laboratory testing. Clin Microbiol Rev Vol.19, No.1, pp. 165-256, ISSN 0893-8512

Fahle, G. A.; \& Fischer, S. H. (2000). Comparison of six commercial DNA extraction kits for recovery of cytomegalovirus DNA from spiked human specimens. J Clin Microbiol Vol.38, No.10, pp. 3860-3, ISSN 0095-1137

Flexman, J.; Kay, I.; Fonte, R.; Herrmann, R.; Gabbay, E.; \& Palladino, S. (2001). Differences between the quantitative antigenemia assay and the cobas amplicor monitor quantitative PCR assay for detecting CMV viraemia in bone marrow and solid organ transplant patients. J Med Virol Vol.64, No.3, pp. 275-82, ISSN 0146-6615 
Forman, M.; Wilson, A.; \& Valsamakis, A. (2011). Cytomegalovirus DNA quantification using an automated platform for nucleic Acid extraction \& real-time PCR assay setup. J Clin Microbiol Vol.49, No.7, pp. 2703-5, ISSN 1098-660X

Gartner, B. C.; Fischinger, J. M.; Litwicki, A.; Roemer, K.; \& Mueller-Lantzsch, N. (2004). Evaluation of a new automated, st\&ardized generic nucleic acid extraction method (total nucleic acid isolation kit) used in combination with cytomegalovirus DNA quantification by COBAS AMPLICOR CMV MONITOR. J Clin Microbiol Vol.42, No.8, pp. 3881-2, ISSN 0095-1137

Gault, E.; Michel, Y.; Dehee, A.; Belabani, C.; Nicolas, J. C.; \& Garbarg-Chenon, A. (2001). Quantification of human cytomegalovirus DNA by real-time PCR. J Clin Microbiol Vol.39, No.2, pp. 772-5, ISSN 0095-1137

Gerna, G.; Lilleri, D.; Caldera, D.; Furione, M.; Zenone Bragotti, L.; \& Aless\&rino, E. P. (2008). Validation of a DNAemia cutoff for preemptive therapy of cytomegalovirus infection in adult hematopoietic stem cell transplant recipients. Bone Marrow Transplant Vol.41, No.10, pp. 873-9, ISSN 0268-3369

Ghisetti, V.; Barbui, A.; Franchello, A.; Varetto, S.; Pittaluga, F.; Bobbio, M.; Salizzoni, M.; \& Marchiaro, G. (2004). Quantitation of cytomegalovirus DNA by the polymerase chain reaction as a predictor of disease in solid organ transplantation. J Med Virol Vol.73, No.2, pp. 223-9, ISSN 0146-6615

Gimeno, C.; Solano, C.; Latorre, J. C.; Hern\&ez-Boluda, J. C.; Clari, M. A.; Remigia, M. J.; Furio, S.; Calabuig, M.; Tormo, N.; \& Navarro, D. (2008). Quantification of DNA in plasma by an automated real-time PCR assay (cytomegalovirus PCR kit) for surveillance of active cytomegalovirus infection and guidance of preemptive therapy for allogeneic hematopoietic stem cell transplant recipients. J Clin Microbiol Vol.46, No.10, pp. 3311-8, ISSN 1098-660X

Gleaves, C. A.; Smith, T. F.; Shuster, E. A.; \& Pearson, G. R. (1984). Rapid detection of cytomegalovirus in MRC-5 cells inoculated with urine specimens by using lowspeed centrifugation and monoclonal antibody to an early antigen. J Clin Microbiol Vol.19, No.6, pp. 917-9, ISSN 0095-1137

Gouarin, S.; Vabret, A.; Scieux, C.; Agbalika, F.; Cherot, J.; Mengelle, C.; Deback, C.; Petitjean, J.; Dina, J.; \& Freymuth, F. (2007). Multicentric evaluation of a new commercial cytomegalovirus real-time PCR quantitation assay. J Virol Methods Vol.146, No.1-2, pp. 147-54, ISSN 0166-0934

Gracia-Ahufinger, I.; Tormo, N.; Espigado, I.; Solano, C.; Urbano-Ispizua, A.; Clari, M. A.; de la Cruz-Vicente, F.; Navarro, D.; \& Perez-Romero, P. (2010). Differences in cytomegalovirus plasma viral loads measured in allogeneic hematopoietic stem cell transplant recipients using two commercial real-time PCR assays. J Clin Virol Vol.48, No.2, pp. 142-6, ISSN 1873-5967

Griffiths, P. D.; Panjwani, D. D.; Stirk, P. R.; Ball, M. G.; Ganczakowski, M.; Blacklock, H. A.; \& Prentice, H. G. (1984). Rapid diagnosis of cytomegalovirus infection in immunocompromised patients by detection of early antigen fluorescent foci. Lancet Vol.2, No.8414, pp. 1242-5, ISSN 0140-6736

Griscelli, F.; Barrois, M.; Chauvin, S.; Lastere, S.; Bellet, D.; \& Bourhis, J. H. (2001). Quantification of human cytomegalovirus DNA in bone marrow transplant recipients by real-time PCR. J Clin Microbiol Vol.39, No.12, pp. 4362-9, ISSN 00951137

Hakki, M.; Riddell, S. R.; Storek, J.; Carter, R. A.; Stevens-Ayers, T.; Sudour, P.; White, K.; Corey, L.; \& Boeckh, M. (2003). Immune reconstitution to cytomegalovirus after allogeneic hematopoietic stem cell transplantation: impact of host factors, drug 
therapy, and subclinical reactivation. Blood Vol.102, No.8, pp. 3060-7, ISSN 00064971

Hanson, K. E.; Reller, L. B.; Kurtzberg, J.; Horwitz, M.; Long, G.; \& Alex\&er, B. D. (2007). Comparison of the Digene Hybrid Capture System Cytomegalovirus (CMV) DNA (version 2.0), Roche CMV UL54 analyte-specific reagent, and QIAGEN RealArt CMV LightCycler PCR reagent tests using AcroMetrix OptiQuant CMV DNA quantification panels and specimens from allogeneic-stem-cell transplant recipients. J Clin Microbiol Vol.45, No.6, pp. 1972-3, ISSN 0095-1137

Harrington, S. M.; Buller, R. S.; Storch, G. A.; Li, L.; Fischer, S. H.; Murray, P. R.; \& GeaBanacloche, J. C. (2007). The effect of quantification standards used in real-time CMV PCR assays on guidelines for initiation of therapy in allogeneic stem cell transplant patients. Bone Marrow Transplant Vol.39, No.4, pp. 237-8, ISSN 0268-3369

Hebart, H.; \& Einsele, H. (2004). Clinical aspects of CMV infection after stem cell transplantation. Hum Immunol 65(5), pp. 432-6.

Herrmann, B.; Larsson, V. C.; Rubin, C. J.; Sund, F.; Eriksson, B. M.; Arvidson, J.; Yun, Z.; Bondeson, K.; \& Blomberg, J. (2004). Comparison of a duplex quantitative real-time PCR assay and the COBAS Amplicor CMV Monitor test for detection of cytomegalovirus. J Clin Microbiol Vol.42, No.5, pp. 1909-14, ISSN 0095-1137

Hong, K. M.; Najjar, H.; Hawley, M.; \& Press, R. D. (2004). Quantitative real-time PCR with automated sample preparation for diagnosis \& monitoring of cytomegalovirus infection in bone marrow transplant patients. Clin Chem Vol.50, No.5, pp. 846-56, ISSN 0009-9147

Humar, A.; Gregson, D.; Caliendo, A. M.; McGeer, A.; Malkan, G.; Krajden, M.; Corey, P.; Greig, P.; Walmsley, S.; Levy, G.; \& Mazzulli, T. (1999). Clinical utility of quantitative cytomegalovirus viral load determination for predicting cytomegalovirus disease in liver transplant recipients. Transplantation Vol.68, No.9, pp. 1305-11, ISSN 0041-1337

Humar, A.; Kumar, D.; Boivin, G.; \& Caliendo, A. M. (2002). Cytomegalovirus (CMV) virus load kinetics to predict recurrent disease in solid-organ transplant patients with CMV disease. J Infect Dis Vol.186, No.6, pp. 829-33, ISSN 0022-1899

Ikewaki, J.; Ohtsuka, E.; Satou, T.; Kawano, R.; Ogata, M.; Kikuchi, H.; \& Nasu, M. (2005). Real-time PCR assays based on distinct genomic regions for cytomegalovirus reactivation following hematopoietic stem cell transplantation. Bone Marrow Transplant Vol.35, No.4, pp. 403-10, ISSN 0268-3369

Kaiser, L.; Perrin, L.; Chapuis, B.; Hadaya, K.; Kolarova, L.; Deffernez, C.; Huguet, S.; Helg, C.; \& Wunderli, W. (2002). Improved monitoring of cytomegalovirus infection after allogeneic hematopoietic stem cell transplantation by an ultrasensitive plasma DNA PCR assay. J Clin Microbiol Vol.40, No.11, pp. 4251-5, ISSN 0095-1137

Kalpoe, J. S.; Kroes, A. C.; de Jong, M. D.; Schinkel, J.; de Brouwer, C. S.; Beersma, M. F.; \& Claas, E. C. (2004). Validation of clinical application of cytomegalovirus plasma DNA load measurement and definition of treatment criteria by analysis of correlation to antigen detection. J Clin Microbiol Vol.42, No.4, pp. 1498-504, ISSN 0095-1137

Kerschner, H.; Bauer, C.; Schlag, P.; Lee, S.; Goedel, S.; \& Popow-Kraupp, T. (2011). Clinical evaluation of a fully automated CMV PCR assay. J Clin Virol Vol.50, No.4, pp. 2816, ISSN 1873-5967

Kim, D. J.; Kim, S. J.; Park, J.; Choi, G. S.; Lee, S.; Kwon, C. D.; Ki, C.; \& Joh, J. (2007). Realtime PCR assay compared with antigenemia assay for detecting cytomegalovirus 
infection in kidney transplant recipients. Transplant Proc Vol.39, No.5, pp. 1458-60, ISSN 0041-1345

Kotton, C. N.; Kumar, D.; Caliendo, A. M.; Asberg, A.; Chou, S.; Snydman, D. R.; Allen, U.; \& Humar, A. (2010). International consensus guidelines on the management of cytomegalovirus in solid organ transplantation. Transplantation Vol.89, No.7, pp. 779-95, ISSN 1534-6080

Ksouri, H.; Eljed, H.; Greco, A.; Lakhal, A.; Torjman, L.; Abdelkefi, A.; Ben Othmen, T.; Ladeb, S.; Slim, A.; Zouari, B.; Abdeladhim, A.; \& Ben Hassen, A. (2007). Analysis of cytomegalovirus (CMV) viremia using the pp65 antigenemia assay, the amplicor CMV test, and a semi-quantitative polymerase chain reaction test after allogeneic marrow transplantation. Transpl Infect Dis Vol.9, No.1, pp. 16-21, ISSN 1398-2273

Lehto, J. T.; Lemstrom, K.; Halme, M.; Lappalainen, M.; Lommi, J.; Sipponen, J.; Harjula, A.; Tukiainen, P.; \& Koskinen, P. K. (2005). A prospective study comparing cytomegalovirus antigenemia, DNAemia and RNAemia tests in guiding preemptive therapy in thoracic organ transplant recipients. Transpl Int Vol.18, No.12, pp. 1318-27, ISSN 0934-0874

Leruez-Ville, M.; Ouachee, M.; Delarue, R.; Sauget, A. S.; Blanche, S.; Buzyn, A.; \& Rouzioux, C. (2003). Monitoring cytomegalovirus infection in adult and pediatric bone marrow transplant recipients by a real-time PCR assay performed with blood plasma. J Clin Microbiol Vol.41, No.5, pp. 2040-6, ISSN 0095-1137

Lilleri, D.; Baldanti, F.; Gatti, M.; Rovida, F.; Dossena, L.; De Grazia, S.; Torsellini, M.; \& Gerna, G. (2004). Clinically-based determination of safe DNAemia cutoff levels for preemptive therapy or human cytomegalovirus infections in solid organ and hematopoietic stem cell transplant recipients. J Med Virol Vol.73, No.3, pp. 412-8, ISSN 0146-6615

Lilleri, D.; Lazzarotto, T.; Ghisetti, V.; Ravanini, P.; Capobianchi, M. R.; Baldanti, F.; \& Gerna, G. (2009). Multicenter quality control study for human cytomegalovirus DNAemia quantification. New Microbiol Vol.32, No.3, 245-53, ISSN 1121-7138

Limaye, A. P.; Huang, M. L.; Leisenring, W.; Stensl\&, L.; Corey, L.; \& Boeckh, M. (2001). Cytomegalovirus (CMV) DNA load in plasma for the diagnosis of CMV disease before engraftment in hematopoietic stem-cell transplant recipients. J Infect Dis Vol.183, No.3, pp. 377-82, ISSN 0022-1899

Ljungman, P.; Griffiths, P.; \& Paya, C. (2002). Definitions of cytomegalovirus infection and disease in transplant recipients. Clin Infect Dis Vol.34, No.8, pp. 1094-7, ISSN 15376591

Ljungman, P.; Perez-Bercoff, L.; Jonsson, J.; Avetisyan, G.; Sparrelid, E.; Aschan, J.; Barkholt, L.; Larsson, K.; Winiarski, J.; Yun, Z.; \& Ringden, O. (2006). Risk factors for the development of cytomegalovirus disease after allogeneic stem cell transplantation. Haematologica Vol.91, No.1, pp. 78-83, ISSN 1592-8721

Mackay, I. M.; Arden, K. E.; \& Nitsche, A. (2002). Real-time PCR in virology. Nucleic Acids Res Vol.30, No.6, pp. 1292-305, ISSN 1362-4962

Machida, U.; Kami, M.; Fukui, T.; Kazuyama, Y.; Kinoshita, M.; Tanaka, Y.; K\&a, Y.; Ogawa, S.; Honda, H.; Chiba, S.; Mitani, K.; Muto, Y.; Osumi, K.; Kimura, S.; \& Hirai, H. (2000). Real-time automated PCR for early diagnosis and monitoring of cytomegalovirus infection after bone marrow transplantation. J Clin Microbiol Vol.38, No.7, pp. 2536-42, ISSN 0095-1137

Martin-Davila, P.; Fortun, J.; Gutierrez, C.; Marti-Belda, P.; C\&elas, A.; Honrubia, A.; Barcena, R.; Martinez, A.; Puente, A.; de Vicente, E.; \& Moreno, S. (2005). Analysis 
of quantitative PCR assay for CMV infection in liver transplant recipients: an intent to find the cut-off value. J Clin Virol Vol.33, pp. 138-144, ISSN 1386-6532

Meijer, E.; Bol\&, G. J.; \& Verdonck, L. F. (2003). Prevention of cytomegalovirus disease in recipients of allogeneic stem cell transplants. Clin Microbiol Rev Vol.16, No.4, pp. 647-57, ISSN 0893-8512

Mengelle, C.; Mansuy, J. M.; Da Silva, I.; Davrinche, C.; \& Izopet, J. (2011). Comparison of 2 highly automated nucleic acid extraction systems for quantitation of human cytomegalovirus in whole blood. Diagn Microbiol Infect Dis Vol.69, No.2, pp. 161-6, ISSN 1879-0070

Mengelle, C.; Pasquier, C.; Rostaing, L.; S\&res-Saune, K.; Puel, J.; Berges, L.; Righi, L.; Bouquies, C.; \& Izopet, J. (2003). Quantitation of human cytomegalovirus in recipients of solid organ transplants by real-time quantitative PCR and pp65 antigenemia. J Med Virol Vol.69, No.2, pp. 225-31, ISSN 0146-6615

Mhiri, L.; Kaabi, B.; Houimel, M.; Arrouji, Z.; \& Slim, A. (2007). Comparison of pp65 antigenemia, quantitative PCR and DNA hybrid capture for detection of cytomegalovirus in transplant recipients \& AIDS patients. J Virol Methods Vol.143, No.1, pp. 23-8, ISSN 0166-0934

Mori, T.; Okamoto, S.; Watanabe, R.; Yajima, T.; Iwao, Y.; Yamazaki, R.; Nakazato, T.; Sato, N.; Iguchi, T.; Nagayama, H.; Takayama, N.; Hibi, T.; \& Ikeda, Y. (2002). Doseadjusted preemptive therapy for cytomegalovirus disease based on real-time polymerase chain reaction after allogeneic hematopoietic stem cell transplantation. Bone Marrow Transplant Vol.29, No.9, pp. 777-82, ISSN 0268-3369

Mori, T.; Sato, N.; Watanabe, R.; Okamoto, S.; \& Ikeda, Y. (2000). Erythema exsudativum multiforme induced by granulocyte colony-stimulating factor in an allogeneic peripheral blood stem cell donor. Bone Marrow Transplant Vol.26, No.2, pp. 239-40, ISSN 0268-3369

Nicholson, V. A.; Whimbey, E.; Champlin, R.; Abi-Said, D.; Przepiorka, D.; Tarr\&, J.; Chan, K.; Bodey, G. P.; \& Goodrich, J. M. (1997). Comparison of cytomegalovirus antigenemia \& shell vial culture in allogeneic marrow transplantation recipients receiving ganciclovir prophylaxis. Bone Marrow Transplant Vol.19, No.1, pp. 37-41, ISSN 0268-3369

Nitsche, A.; Steuer, N.; Schmidt, C. A.; L\&t, O.; Ellerbrok, H.; Pauli, G.; \& Siegert, W. (2000). Detection of human cytomegalovirus DNA by real-time quantitative PCR. J Clin Microbiol Vol.38, No.7, pp. 2734-7, ISSN 0095-1137

Nitsche, A.; Steuer, N.; Schmidt, C. A.; O.; \& Siegert, W. (1999). Different real-time PCR formats compared for the quantitative detection of human cytomegalovirus DNA. Clin Chem Vol.45, No.11, pp. 1932-7, ISSN 0009-9147

Ozdemir, E.; Saliba, R. M.; Champlin, R. E.; Couriel, D. R.; Giralt, S. A.; de Lima, M.; Khouri, I. F.; Hosing, C.; Kornblau, S. M.; Anderlini, P.; Shpall, E. J.; Qazilbash, M. H.; Molldrem, J. J.; Chemaly, R. F.; \& Komanduri, K. V. (2007). Risk factors associated with late cytomegalovirus reactivation after allogeneic stem cell transplantation for hematological malignancies. Bone Marrow Transplant Vol.40, No.2, pp. 125-36, ISSN 0268-3369

Pang, X. L.; Fox, J. D.; Fenton, J. M.; Miller, G. G.; Caliendo, A. M.; \& Preiksaitis, J. K. (2009). Interlaboratory comparison of cytomegalovirus viral load assays. Am J Transplant Vol.9, No.2, pp. 258-68, ISSN 1600-6143

Piiparinen, H.; Helantera, I.; Lappalainen, M.; Suni, J.; Koskinen, P.; Gronhagen-Riska, C.; \& Lautenschlager, I. (2005). Quantitative PCR in the diagnosis of CMV infection and 
in the monitoring of viral load during the antiviral treatment in renal transplant patients. J Med Virol Vol.76, No.3, pp. 367-72, ISSN 0146-6615

Preiser, W.; Brauninger, S.; Schwerdtfeger, R.; Ayliffe, U.; Garson, J. A.; Brink, N. S.; Franck, S.; Doerr, H. W.; \& Rabenau, H. F. (2001). Evaluation of diagnostic methods for the detection of cytomegalovirus in recipients of allogeneic stem cell transplants. J Clin Virol Vol.20, No.1-2, pp. 59-70, ISSN 1386-6532

Pumannova, M.; Roubalova, K.; Vitek, A.; \& Sajdova, J. (2006). Comparison of quantitative competitive polymerase chain reaction-enzyme-linked immunosorbent assay with LightCycler-based polymerase chain reaction for measuring cytomegalovirus DNA in patients after hematopoietic stem cell transplantation. Diagn Microbiol Infect Dis Vol.54, No.2, pp. 115-20, ISSN 0732-8893

Raggam, R. B.; Bozic, M.; Salzer, H. J.; Hammerschmidt, S.; Homberg, C.; Ruzicka, K.; \& Kessler, H. H. (2010). Rapid quantitation of cytomegalovirus DNA in whole blood by a new molecular assay based on automated sample preparation \& real-time PCR. Med Microbiol Immunol Vol.199, No.4, pp. 311-6, ISSN 1432-1831

Razonable, R. R.; Brown, R. A.; Wilson, J.; Groettum, C.; Kremers, W.; Espy, M.; Smith, T. F.; \& Paya, C. V. (2002). The clinical use of various blood compartments for cytomegalovirus (CMV) DNA quantitation in transplant recipients with CMV disease. Transplantation Vol.73, No.6, pp. 968-73, ISSN 0041-1337

Razonable, R. R.; \& Emery, V. C. (2004). Management of CMV infection and disease in transplant patients. 27-29 February 2004. Herpes Vol.11, No.3, pp. 77-86, ISSN 09697667

Ruell, J.; Barnes, C.; Mutton, K.; Foulkes, B.; Chang, J.; Cavet, J.; Guiver, M.; Menasce, L.; Dougal, M.; \& Chopra, R. (2007). Active CMV disease does not always correlate with viral load detection. Bone Marrow Transplant Vol.40, No.1, pp. 55-61, ISSN 0268-3369

Schaade, L.; Kockelkorn, P.; Ritter, K.; \& Kleines, M. (2000). Detection of cytomegalovirus DNA in human specimens by LightCycler PCR. J Clin Microbiol Vol.38, No.11, pp. 4006-9, ISSN 0095-1137

Sia, I. G.; \& Patel, R. (2000). New strategies for prevention \& therapy of cytomegalovirus infection and disease in solid-organ transplant recipients. Clin Microbiol Rev Vol.13, No.1, 83-121, ISSN 0893-8512

Sia, I. G.; Wilson, J. A.; Espy, M. J.; Paya, C. V.; \& Smith, T. F. (2000). Evaluation of the COBAS AMPLICOR CMV MONITOR test for detection of viral DNA in specimens taken from patients after liver transplantation. J Clin Microbiol Vol.38, No.2, pp. 6006, ISSN 0095-1137

Solano, C.; Munoz, I.; Gutierrez, A.; Farga, A.; Prosper, F.; Garcia-Conde, J.; Navarro, D.; \& Gimeno, C. (2001). Qualitative plasma PCR assay (AMPLICOR CMV test) versus pp65 antigenemia assay for monitoring cytomegalovirus viremia \& guiding preemptive ganciclovir therapy in allogeneic stem cell transplantation. J Clin Microbiol Vol.39, No.11, pp. 3938-41, ISSN 0095-1137

Stocher, M.; Leb, V.; Bozic, M.; Kessler, H. H.; Halwachs-Baumann, G.; O.; Stekel, H.; \& Berg, J. (2003). Parallel detection of five human herpes virus DNAs by a set of real-time polymerase chain reactions in a single run. J Clin Virol Vol.26, No.1, pp. 85-93, ISSN 1386-6532

Tanaka, N.; Kimura, H.; Iida, K.; Saito, Y.; Tsuge, I.; Yoshimi, A.; Matsuyama, T.; \& Morishima, T. (2000). Quantitative analysis of cytomegalovirus load using a realtime PCR assay. J Med Virol Vol.60, No.4, pp. 455-62, ISSN 0146-6615 
Tanaka, Y.; K\&a, Y.; Kami, M.; Mori, S.; Hamaki, T.; Kusumi, E.; Miyakoshi, S.; Nannya, Y.; Chiba, S.; Arai, Y.; Mitani, K.; Hirai, H.; \& Mutou, Y. (2002). Monitoring cytomegalovirus infection by antigenemia assay \& two distinct plasma real-time PCR methods after hematopoietic stem cell transplantation. Bone Marrow Transplant Vol.30, No.5, pp. 315-9, ISSN 0268-3369

Tormo, N.; Solano, C.; Benet, I.; Clari, M. A.; Nieto, J.; de la Camara, R.; Lopez, J.; LopezAldeguer, N.; Hern\&ez-Boluda, J. C.; Remigia, M. J.; Garcia-Noblejas, A.; Gimeno, C.; \& Navarro, D. (2010). Lack of prompt expansion of cytomegalovirus pp65 and IE-1-specific IFNgamma CD8+ and CD4+ T cells is associated with rising levels of pp65 antigenemia and DNAemia during pre-emptive therapy in allogeneic hematopoietic stem cell transplant recipients. Bone Marrow Transplant Vol.45, No.3, pp. 543-9, ISSN 1476-5365

Valentine-Thon, E. (2002). Quality control in nucleic acid testing--where do we stand? J Clin Virol Vol.25, No.Suppl 3, pp. S13-21, ISSN 1386-6532

Van der Bij, W.; Schirm, J.; Torensma, R.; Van Son, W. J.; Tegzess, A. M.; \& The, T. H. (1988). Comparison between Viremia and Antigenemia for Detection of Cytomegalovirus in Blood. J Clin Microbiol Vol.26, No.12, pp. 5, ISSN 0095-1137

Verkruyse, L. A.; Storch, G. A.; Devine, S. M.; Dipersio, J. F.; \& Vij, R. (2006). Once daily ganciclovir as initial pre-emptive therapy delayed until threshold CMV load $>$ or $=10000$ copies $/ \mathrm{ml}$ : a safe and effective strategy for allogeneic stem cell transplant patients. Bone Marrow Transplant Vol.37, No.1, pp. 51-6, ISSN 0268-3369

von Muller, L.; Hinz, J.; Bommer, M.; Hampl, W.; Kluwick, S.; Wiedmann, M.; Bunjes, D.; \& Mertens, T. (2007). CMV monitoring using blood cells and plasma: a comparison of apples with oranges? Bone Marrow Transplant Vol.39, No.6, pp. 353-7, ISSN 02683369

Wang, W.; Patterson, C. E.; Yang, S.; \& Zhu, H. (2004). Coupling generation of cytomegalovirus deletion mutants and amplification of viral BAC clones. J Virol Methods Vol.121, No.2, pp. 137-43, ISSN 0166-0934

Weinberg, A.; Schissel, D.; \& Giller, R. (2002). Molecular methods for cytomegalovirus surveillance in bone marrow transplant recipients. J Clin Microbiol Vol.40, No.11, 4203-6, ISSN 0095-1137

Westall, G. P.; Michaelides, A.; Williams, T. J.; Snell, G. I.; \& Kotsimbos, T. C. (2004). Human cytomegalovirus load in plasma and bronchoalveolar lavage fluid: a longitudinal study of lung transplant recipients. J Infect Dis Vol.190, No.6, pp. 1076-83, ISSN 0022-1899

Yakushiji, K.; Gondo, H.; Kamezaki, K.; Shigematsu, K.; Hayashi, S.; Kuroiwa, M.; Taniguchi, S.; Ohno, Y.; Takase, K.; Numata, A.; Aoki, K.; Kato, K.; Nagafuji, K.; Shimoda, K.; Okamura, T.; Kinukawa, N.; Kasuga, N.; Sata, M.; \& Harada, M. (2002). Monitoring of cytomegalovirus reactivation after allogeneic stem cell transplantation: comparison of an antigenemia assay and quantitative real-time polymerase chain reaction. Bone Marrow Transplant Vol.29, No.7, pp. 599-606, ISSN 0268-3369

Yun, Z.; Lewensohn-Fuchs, I.; Ljungman, P.; Ringholm, L.; Jonsson, J.; \& Albert, J. (2003). A real-time TaqMan PCR for routine quantitation of cytomegalovirus DNA in crude leukocyte lysates from stem cell transplant patients. J Virol Methods Vol.110, No.1, pp. 73-9, ISSN 0166-0934

Zaia, J. A. (2002). Prevention of cytomegalovirus disease in hematopoietic stem cell transplantation. Clin Infect Dis Vol.35, No.8, pp. 999-1004, ISSN 1537-6591 


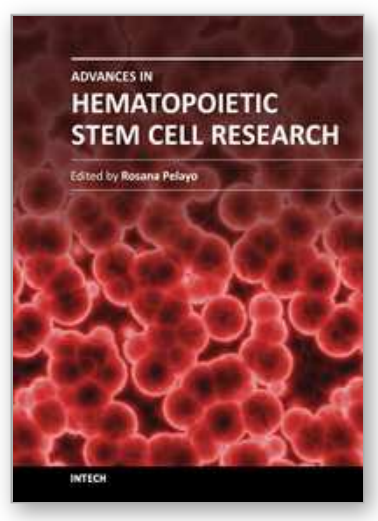

\author{
Advances in Hematopoietic Stem Cell Research \\ Edited by Dr. Rosana Pelayo
}

ISBN 978-953-307-930-1

Hard cover, 464 pages

Publisher InTech

Published online 27, January, 2012

Published in print edition January, 2012

This book provides a comprehensive overview in our understanding of the biology and therapeutic potential of hematopoietic stem cells, and is aimed at those engaged in stem cell research: undergraduate and postgraduate science students, investigators and clinicians. Starting from fundamental principles in hematopoiesis, Advances in Hematopoietic Stem Cell Research assemble a wealth of information relevant to central mechanisms that may regulate differentiation, and expansion of hematopoietic stem cells in normal conditions and during disease.

\title{
How to reference
}

In order to correctly reference this scholarly work, feel free to copy and paste the following:

Pilar Blanco-Lobo, Omar J. BenMarzouk-Hidalgo and Pilar Pérez-Romero (2012). Detection of CMV Infection in Allogeneic SCT Recipients: The Multiple Assays, Advances in Hematopoietic Stem Cell Research, Dr. Rosana Pelayo (Ed.), ISBN: 978-953-307-930-1, InTech, Available from: http://www.intechopen.com/books/advances-in-hematopoietic-stem-cell-research/detection-of-cmv-infection-inallogeneic-sct-recipients-the-multiple-assays

\section{INTECH}

open science | open minds

\section{InTech Europe}

University Campus STeP Ri

Slavka Krautzeka 83/A

51000 Rijeka, Croatia

Phone: +385 (51) 770447

Fax: +385 (51) 686166

www.intechopen.com

\section{InTech China}

Unit 405, Office Block, Hotel Equatorial Shanghai

No.65, Yan An Road (West), Shanghai, 200040, China

中国上海市延安西路65号上海国际贵都大饭店办公楼405单元

Phone: +86-21-62489820

Fax: +86-21-62489821 
(C) 2012 The Author(s). Licensee IntechOpen. This is an open access article distributed under the terms of the Creative Commons Attribution 3.0 License, which permits unrestricted use, distribution, and reproduction in any medium, provided the original work is properly cited. 